\title{
DESAIN MATERI PENDIDIKAN KOSMOLOGI (KAWNIYYAH) PERSPEKTIF AL-QURAN
}

Ah. Zakki Fuad

(Dosen FTK Universitas Islam Negeri Sunan Ampel Prodi PAI)

\begin{abstract}
Uncontrolled exploitation and utilization of natural resources in Indonesia has caused several natural disasters with victims and financial-material loss. The disasters would not happen if human beings has better understanding about the universe. Therefore, the next generations must be prepared with cosmology/kawniyyah in educational institutions. A more applicative cosmology in school is urgently needed. In a framework of thematic approach, Quranic verses are widely opened for the instructional material in educational institutions. Cosmological mystery in the Quran is defined into the following three categories: (1) land cosmology involving the earth, soil, plants, and animals; (2) sea cosmology including water and fishes; and (3) space cosmology mentioning the sun, the moon, clouds, rains, and winds. Better understanding of cosmology prevents human beings from natural disaster.
\end{abstract}

Key words: Cosmology, Instructional Materials, and Al-Quran

\section{Abstrak}

Eksploitasi dan pemanfaatan sumber kekayaan alam yang berlebihan dan tidak terkendali di Indonesia telah mengakibatkan banyak bencana alam yang menelan korban jiwa dan harta. Bencana alam ini tidak akan terjadi apabila manusia mempunyai hubungan dan pengetahuan yang baik tentang alam semesta. Hal yang harus dilakukan adalah menyiapkan generasi masa depan dengan bekal ilmu yang cukup tentang kosmos/alam semesta/kawniyyah melalui lembaga-lembaga pendidikan. Lembaga pendidikan sebagai desainer harus menyiapkan materi 
pendidikan kosmologi bagi peserta didik yang baik dan aplikatif. Materi pendidikan kosmologi banyak ditemukan dalam ayat-ayat kawniyyah dalam al-Quran, tetapi ayat-ayat tersebut masih belum didesain sebagi sebuah teori yang aplikatif bagi lembaga pendidikan. Dengan pendekatan tematik (mawdhu'i) ayat-ayat al-Quran yang masih sangat luas bisa dibuat menjadi desain materi pendidikan kosmologi bagi lembaga pendidikan. Materi pendidikan kosmologi dalam al-Quran dibagi menjadi tiga jenis; 1) Kosmologi daratan yang meliputi bumi, tanah, tumbuhtumbuhan dan hewan. 2) Kosmologi lautan yang meliputi air dan perikanan. 3) Kosmologi angkasa yang meliputi matahari, bulan, bintang, awan, hujan dan angin. Pengetahuan dan pemahaman yang baik tentang kosmologi akan menghindarkan manusia dari musibah dan bencana alam.

Kata Kunci: Kosmologi, Materi Pendidikan, dan Al-Quran

\section{A. Pendahuluan}

Materi pendidikan didesain sebagai bekal bagi peserta didik dalam menjalani kehidupannya setelah lulus dari lembaga pendidikan. ${ }^{1}$ Oleh karena itu materi pendidikan yang baik adalah materi yang sesuai dengan kondisi dimana peserta didik itu hidup dan bersosialisasi dengan pranata sosial lainnya. ${ }^{2}$ Realitas yang terjadi sekarang di daerah-daerah hampir di seluruh Indonesia telah terjadi eksploitasi dan pemanfaatan sumber kekayaan alam yang berlebihan dan tidak terkendali yang mengakibatkan bencana alam yang menelan banyak korban jiwa dan harta. Hal ini menjadi tanggung jawab pendidikan untuk menyiapkan peserta didiknya untuk bisa menyikapi dan berinteraksi dengan baik terhadap alam semesta.

1 Tim Penulis Bahan Ajar PLPG, Perangkat Pembelajaran (Surabaya: LPTK Fak. Tarbiyah Surabaya, 2011).

2 M. Arifin, Ilmu Pendidikan Islam: Suatu Tinjauan Teoritis dan Praktis Berdasarkan Pendekatan Interdisipliner (Jakarta: Bumi Aksara, 1993). 
Lembaga pendidikan sebagai desainer materi pendidikan harus bisa merancang materi yang bisa menjadikan peserta didik untuk dapat mengelola dan memanfaatkan alam semesta dan sumber dayanya dengan bijaksana, menghindari terjadinya bencana alam dan kekacauan serta ketidakteraturan alam semesta. Oleh karena itu diperlukan materi pendidikan kosmologi/alam semesta (kawniyyah) dalam pembelajaran di lembaga-lembaga pendidikan terutama lembaga pendidikan Islam.

Lembaga pendidikan harus mengajarkan materi supaya peserta didik tidak melakukan perusakan di bumi ini yang meliputi daratan dengan berbagai sumber kekayaan alamnya, lautan dengan potensi kekayaan ikannya, air sebagai sumber kehidupan yang di era global seperti sekarang ini semua dieksploitasi dan dimanfaatkan secara maksimal tanpa berpikir bahwa semua itu akan habis; termasuk hewan, ikan, tumbuhan, tanaman.

Desain ideal materi pendidikan kosmologi (kawniyyah) harus digali dari al-Quran sebagai sumber ilmu pengetahuan yang tidak terbatas supaya teori yang dihasilkan bisa valid dan mampu diimplementasikan di lembaga-lembaga pendidikan. Tulisan ini berusaha menemukan teori tentang materi pendidikan kosmologi/alam semesta (kawniyyah) dari al-Quran dengan pendekatan tematik. ${ }^{3}$

3 Langkah-langkah metode tafsir tematik (mawdhu'iy) yang dikemukakan oleh AlFarmawi yaitu: a) Menghimpun ayat-ayat yang berkaitan dengan judul di atas dengan memasukkan kata kunci pada software komputer. b) Mengalisis korelasi (munasabat) ayat-ayat yang sesuai dengan judul penelitian. Munasabat dibagi menjadi 2 (dua) yaitu: Zahir ar-Irtibat (persesuaian yang nyata) dan khafiy al-Irtibat (persambungan yang tidak jelas). c) Mengaji asbab al-Nuzul-nya. Sebab-sebab turunya ayat ini diperlukan dalam rangka mengetahui hikmah turunnya ayat. d) Melengkapi dengan hadis-hadis yang relevan serta pendapat para ulama sebagai pendukung. e) Melakukan interpretasi ayat serta merumuskannya. f) Menyimpulkan hasil interpretasi yang menjadi hasil dari penelitian. Baca Abd Hayy Farmawi, Al-Bidayah fi al-Tafsir Maudhu'i, Dirasah Manhajiyyah Maudhu'iyyah, Terj. Rosihan Anwar (Bandung: Pustaka Setia, 2002). Sebagai perbandingan serta untuk mengetahui posisi tafsir mawdu'iy di antara metode tafsir yang lain bisa diuraikan sebagai berikut: Pertama, metode penafsiran dilihat dari segi sumbernya terbagi menjadi metode tafsir bi al-Ma'thsur/bi al-Manqul (cara menafsirkan ayat-ayat al-Quran yang didasarkan kepada al-Quran, al-Hadits, Riwayat sahabat dan tabi'in), metode tafsir bi al-Ra'yi/bi al-Riwayah (cara menafsirkan alQuran dengan landasan ijtihad, pemikiran ahli tafsir, kaidah bahasa dan sosial), metode tafsir bi al-Iqtirani (perpaduan bi al-Ma'qul dengan al-Manqul (cara 


\section{B. Pengertian Kosmologi (Kawniyyah)}

Kosmologi berasal dari bahasa Yunani, kosmos (susunan) dan logos (keteraturan). Kosmologi adalah ilmu yang menyelidiki asalusul, struktur, hubungan antara ruang dan waktu dalam alam semesta, ilmu tentang asal usul kejadian bumi, hubungannya dengan sistem matahari, jagat raya, ilmu (cabang dari metafisika) yang mempelajari alam semesta sebagai sistem yang beraturan. ${ }^{4}$ Kosmologi sebagai ilmu (cabang filsafat) yang mempelajari tentang struktur, susunan dan keteraturan alam semesta sudah diperkenalkan oleh Cristian V. Wolff tahun 1728 M. Kosmologi diajarkan di lembaga pendidikan semata bertujuan untuk memberikan bekal bagi peserta didik tentang pengetahuan tentang alam semesta dan segala isinya supaya lulusan lembaga pendidikan mampu mengetahui, memanfaatkan dan mengelola sumber daya alam semesta secara bijak dan terkendali.

Al-Quran menjelaskan tentang alam semesta dengan segala isinya dengan ayat-ayat kawniyyah yang dari sisi akademis belum banyak dieksplorasi menjadi sebuah temuan teori yang bermanfaat bagi dunia pendidikan. Temuan-temuan teori dari al-Quran yang "membumi" tentang kosmologi sangat membantu dunia yang

menafsirkan al-Quran didasarkan atas perpaduan antara sumber riwayat yang shahih dan ijtihad yang kuat). Kedua, metode penafsiran dilihat dari segi cara penjelasannya terbagi menjadi metode bayani/metode deskripsi dan metode muqarrin/komparasi. Ketiga, metode penafsiran dilihat dari segi kekuatan dan keluasan penjelasannya terbagi menjadi metode tafsir Ijmaly dan metode tafsir Itnabi. Keempat, metode penafsiran dilihat dari sasaran dan tertib ayat terbagi menjadi metode tafsir Tahlily dan metode Tafsir mawdhu'iy. Sedangkan kecenderungan (naz'ah) adalah arah penafsiran dari seorang mufassir dalam menafsirkan ayat-ayat al-Quran. Dari kecenderungan ini muncullah aliran-aliran (ittijah) tafsir, yaitu tafsir lughawi/adabi, al-Fiqhi, sufi, i'tiqadi, falsafi, 'asri/ilmi, ijtima'i. Tafsir Lughawi, tafsir yang menitik beratkan pada aspek bahasa, meliputi i'rab, susunan kalimat dan qaidah yang lain. Seperti al-Kassaf karangan Zamakhsari, tafsir al-Fikih yaitu tafsir yang menitikberatkan kajiannya pada aspek hukum. Seperti tafsir al-Qurtubi, tafsir Shufi yaitu tafsir yang menitikberatkan pada aspek tasawwuf atau kejiwan, tafsir Falsafi yaitu tafsir yang titik sentralnya pada kajian bidang filsafat dan pemikiran filsafat, tafsir 'asri/ilmi yaitu tafsir yang titik sentralnya pada ilmu kajian umum seperti ayat-ayat kawniyah, sedangkan tafsir Ijtima, yaitu tafsir yang berusaha melibatkan masyarakat dan fakta sosial yang berkembang. Baca M. Ridlwan Nasir, Memahami al-Quran Perspektif Baru Tafsir Muqarrin (Surabaya: Indra Media, 2003), 14-17.

${ }^{4}$ Kamus Besar Bahasa Indonesia (Jakarta: Balai Pustaka, 2005), 597. 
sekarang ini sudah mengalami krisis etika dalam berinteraksi dengan alam semesta, terjadi perusakan alam dan eksploitasi yang berlebihan terhadap sumber daya alam. Di sini peran pendidikan menjadi sangat penting dalam membekali peserta didiknya supaya lulusan yang dihasilkan dapat memahami, mengatur, memanfaatkan alam dengan bijaksana dan baik.

\section{Kosmologi dalam Al-Quran}

Alam semesta yang mencakup makrokosmos dan mikrokosmos dalam al-Quran dijelaskan melalui ayat-ayat kawniyyah yang mengeksplorasi bagian-bagian alam semesta dan bagaimana mengelola sember daya alam semesta tersebut secara benar. Ayatayat al-Quran menjelaskan banyak hal tentang materi-materi kosmologi/kawniyyah yang harus dipelajari peserta didik di lembaga pendidikan yang meliputi alam semesta yang ada di daratan, lautan dan luar angkasa.

\section{Daratan}

a. Bumi

Al-Quran surat ke-2 ayat ke-11 menjelaskan: "Dan bila dikatakan kepada mereka; Janganlah kamu membuat kerusakan di muka bumi. Mereka menjawab; Sesungguhnya kami orangorang yang mengadakan perbaikan". Ayat tersebut bermakna orang-orang yang memelihara nilai-nilai sesuatu sehingga kondisinya tetap tidak berubah sebagaimana adanya, sehingga sesuatu itu tetap berfungsi dengan baik dan bermanfaat seperti alam dan isinya masuk kategori mushlihun, yaitu orang-orang yang menemukan, memperbaiki sesuatu yang hilang atau berkurang nilainya; tidak berfungsinya sesuatu, kurang manfaatnya sesuatu kemudian melakukan aktifitas (memperbaiki) sehingga sesuatu itu bisa menyatu kembali. Ibnu Jawzi memberikan makna mushlihun pada ayat tersebut sebagai orang-orang yang tidak mengerjakan sesuatu yang menjadikan 
kerusakan. ${ }^{5}$

Kemudian al-Quran surat ke-7 ayat ke-85 menyatakan: "Dan (kami telah mengutus) kepada penduduk Madyan6 saudara mereka, Syu'aib, ia berkata; Hai kaumku, sembahlah Allah, sekali-kali tidak ada Tuhan bagimu selain-Nya. Sesungguhnya telah datang kepadamu bukti yang nyata dari Tuhanmu. Maka sempurnakanlah takaran dan timbangan dan janganlah kamu kurangkan bagi manusia barang-barang takaran dan timbangannya dan janganlah kamu membuat kerusakan di muka bumi sesudah Tuhan memperbaikinya. Yang demikian itu lebih baik bagimu jika betul-betul kamu orangorang yang beriman".

Ayat al-Quran surat ke-7 ayat ke-85 di atas diantaranya mengandung ajaran bahwa manusia dilarang untuk merusak segala sesuatu yang ada di bumi. Merusak ini mencakup perusakan terhadap alam semesta, harta benda, keturunan maupun jiwa manusia yang pada akhirnya menyebabkan manusia hidup dalam keadaan tidak aman dan tidak punya rasa tenteram. Kecurangan terhadap transaksi jual beli dengan mengurangi takaran dan timbangan itu termasuk membuat kerusakan karena menjadikan manusia tidak tenteram dan dirugikan.

\footnotetext{
${ }^{5}$ Ibnu Jawzi, Zad al-Masir, dalam Al-Maktabah al-Syamilah, Akbar al-Mausuah Islamiyyah, Ihdhar Thani, 3. Ayat tersebut diturunkan tentang perilaku orang munafik yang selalu melakukan kerusakan yang ada di bumi. Bentuk-bentuk pengrusakan yang dilakukan diantaranya: Pengrusakan terhadap dirinya sendiri dengan cara ketika dia sakit mereka enggan berobat sehingga sakitnya semakin parah; Pengerusakan terhadap anak-anak dan keluarganya dengan cara menularkan sifat-sifat yang buruk kepada anak dan keluarganya; Pengrusakan terhadap masyarakat dengan cara menyebarkan isu-isu negatif, menanamkan kebencian dan perpecahan di masyarakat. ${ }^{6}$ Madyan adalah nama putera Nabi Ibrahim as, kemudian menjadi nama kabilah yang terdiri dari anak cucu Madyan itu. Kabilah ini diam di suatu tempat yang juga dinamai Madyan yang terletak di pantai laut merah di tenggara gunung Sinai, yakni antara Hijaz, tepatnya Tabuk di Saudi Arabia dan teluk Aqabah. Menurut sejarahwan populasi mereka sekitar 25.000 ribu orang. Ibnu 'Ashur, Al-Tahrir wa Al-Tanwir dalam AlMaktabah al-Syamilah, Akbar al-Mausuah Islamiyyah, Ihdhar Thani, 161.
} 


\section{b. Tanah}

Al-Quran surat ke-33 ayat ke-27 menerangkan: "Dan Dia mewariskan kepada kamu tanah-tanah, rumah-rumah dan harta benda mereka, dan (begitu pula) tanah yang belum kamu injak. Ddan adalah Allah Maha Kuasa terhadap segala sesuatu". Kemudian al-Quran surat ke-7 ayat ke-58 menyatakan: "Dan tanah yang baik, tanaman-tanamannya tumbuh subur dengan seizin Allah; dan tanah yang tidak subur, tanaman-tanamannya hanya tumbuh merana. Demikianlah kami mengulangi tandatanda kebesaran (Kami) bagi orang-orang yang bersyukur".

\section{c. Tumbuhan}

Al-Quran surat ke-6 ayat ke-99 menjelaskan: "Dan dialah yang menurunkan air hujan dari langit, lalu kami tumbuhkan dengan air itu segala macam tumbuh-tumbuhan, Maka Kami keluarkan dari tumbuh-tumbuhan itu tanaman yang menghijau. Kami keluarkan dari tanaman yang menghijau itu butir yang banyak; dan dari mayang korma mengurai tangkai-tangkai yang menjulai, dan kebun-kebun anggur, dan (Kami keluarkan pula) zaitun dan delima yang serupa dan yang tidak serupa. Perhatikanlah buahnya di waktu pohonnya berbuah dan (perhatikan pulalah) kematangannya. Sesungguhnya pada yang demikian itu ada tanda-tanda (kekuasaan Allah) bagi orangorang yang beriman".

Kemudian al-Quran surat ke-16 ayat ke-10 menjelaskan: "Dia-lah yang telah menurunkan air hujan dari langit untuk kamu, sebagiannya menjadi minuman dan sebagiannya (menyuburkan) tumbuh-tumbuhan, yang pada (tempat tumbuhnya) kamu menggembalakan ternakmu".

d. Hewan

Al-Quran surat ke-24 ayat ke-45 menyatakan: "Dan Allah telah menciptakan semua jenis hewan dari air, Maka sebagian dari hewan itu ada yang berjalan di atas perutnya dan sebagian berjalan dengan dua kaki sedang sebagian (yang lain) berjalan dengan empat kaki. Allah menciptakan apa yang dikehendaki- 
Nya, sesungguhnya Allah Maha Kuasa atas segala sesuatu".

Dalam pada itu al-Quran surat ke-6 ayat ke-138 menjelaskan: "Dan mereka mengatakan inilah hewan ternak dan tanaman yang dilarang; tidak boleh memakannya, kecuali orang yang kami kehendaki, menurut anggapan mereka, dan ada binatang ternak yang diharamkan menungganginya dan ada binatang ternak yang mereka tidak menyebut nama Allah waktu menyembelihnya, semata-mata membuat-buat kedustaan terhadap Allah. kelak Allah akan membalas mereka terhadap apa yang selalu mereka ada-adakan.

\section{Lautan}

a. Air

Al-Quran surat ke-13 ayat ke-17 menyatakan: "Allah telah menurunkan air (hujan) dari langit, maka mengalirlah air di lembah-lembah menurut ukurannya, maka arus itu membawa buih yang mengambang. Dan dari apa (logam) yang mereka lebur dalam api untuk membuat perhiasan atau alat-alat, ada (pula) buihnya seperti buih arus itu. Demikianlah Allah membuat perumpamaan (bagi) yang benar dan yang bathil. Adapun buih itu, akan hilang sebagai sesuatu yang tak ada harganya; adapun yang memberi manfaat kepada manusia, maka ia tetap di bumi. Demikianlah Allah membuat perumpamaan-perumpamaan".

Kemudian al-Quran surat ke-39 ayat ke-21 menjelaskan: "Apakah kamu tidak memperhatikan, bahwa sesungguhnya Allah menurunkan air dari langit, maka diaturnya menjadi sumber-sumber air di bumi kemudian ditumbuhkan-Nya dengan air itu tanam-tanaman yang bermacam-macam warnanya, lalu menjadi kering lalu kamu melihatnya kekuningkuningan, kemudian dijadikan-Nya hancur berderai-derai. Sesungguhnya pada yang demikian itu benar-benar terdapat pelajaran bagi orang-orang yang mempunyai akal". 
b. Perikanan

Al-Quran surat ke-7 ayat ke-163 menyebutkan: "Dan tanyakan kepada Bani Israil tentang negeri yang terletak di dekat laut ketika mereka melanggar aturan pada hari Sabtu, di waktu datang kepada mereka ikan-ikan (yang berada di sekitar) mereka terapung-apung di permukaan air, dan di hari-hari yang bukan Sabtu, ikan-ikan itu tidak datang kepada mereka. Demikianlah kami mencoba mereka disebabkan mereka berlaku fasik".

Sementara itu al-Quran surat ke-18 ayat ke-63 menjelaskan: "Muridnya menjawab; Tahukah kamu tatkala kita mecari tempat berlindung di batu tadi, maka sesungguhnya aku lupa (menceritakan tentang) ikan itu dan tidak adalah yang melupakan aku untuk menceritakannya kecuali syaitan dan ikan itu mengambil jalannya ke laut dengan cara yang aneh sekali".

\section{Luar Angkasa}

a. Matahari

Al-Quran surat ke-41 ayat ke-37 menerangkan: "Dan di antara tanda-tanda kekuasaan-Nya ialah malam, siang, matahari dan bulan. Janganlah sembah matahari maupun bulan, tapi sembahlah Allah yang menciptakannya...". sedangkan al-Quran surat ke-2 ayat ke-258 menyatakan: "Apakah kamu tidak memperhatikan orang yang mendebat Ibrahim tentang Tuhannya (Allah) Karena Allah telah memberikan kepada orang itu pemerintahan (kekuasaan). Ketika Ibrahim mengatakan; Tuhanku ialah yang menghidupkan dan mematikan, orang itu berkata; Saya dapat menghidupkan dan mematikan. Ibrahim berkata; Sesungguhnya Allah menerbitkan matahari dari Timur, maka terbitkanlah dia dari Barat, lalu terdiam orang kafir itu, dan Allah tidak memberikan petunjuk kepada orang-orang yang zalim". 
b. Bintang

Al-Quran surat ke-15 ayat ke-16 menjelaskan: "Dan sesungguhnya Kami telah menciptakan gugusan bintangbintang (di langit) dan Kami telah menghiasi langit itu bagi orang-orang yang memandangnya". Kemudian al-Quran surat ke-37 ayat ke-6 memberitakan: "Sesungguhnya Kami telah menghiasi langit yang terdekat dengan hiasan, yaitu bintangbintang".

c. Bulan

Al-Quran surat ke-41 ayat ke-37 menyatakan: "Dan di antara tanda-tanda kekuasaan-Nya ialah malam, siang, matahari dan bulan. Janganlah sembah matahari maupun bulan, tapi sembahlah Allah yang menciptakannya...". Lalu al-Quran surat ke-10 ayat ke-5 menjelaskan: "Dialah yang menjadikan matahari bersinar dan bulan bercahaya dan ditetapkan-Nya manzilahmanzilah (tempat-tempat) bagi perjalanan bulan itu, supaya kamu mengetahui bilangan tahun dan perhitungan (waktu). Allah tidak menciptakan yang demikian itu melainkan dengan benar. Dia menjelaskan tanda-tanda (kebesaran-Nya) kepada orang-orang yang mengetahui".

d. Awan

Al-Quran surat ke-35 ayat ke-9 menjelaskan: "Dan Allah, Dialah yang mengirimkan angin, lalu angin itu menggerakkan awan, maka Kami halau awan itu ke suatu negeri yang mati lalu Kami hidupkan bumi setelah matinya dengan hujan itu. Demikianlah kebangkitan itu". Allah SWT di dalam al-Quran surat ke-24 ayat ke-43 juga menjelaskan: "Tidaklah kamu melihat bahwa Allah mengarak awan, kemudian mengumpulkan antara (bagian-bagian)nya, kemudian menjadikannya bertindihtindih, maka kelihatanlah olehmu hujan keluar dari celahcelahnya dan Allah (juga) menurunkan (butiran-butiran) es dari langit, (yaitu) dari (gumpalan-gumpalan awan (seperti) gununggunung, maka ditimpakan-Nya (butiran-butiran) es itu kepada siapa yang dikehendaki-Nya dan dipalingkan-Nya dari siapa 
yang dikehendaki-Nya. Kilauan kilat awan itu hampir-hampir menghilangkan penglihatan".

e. Hujan

Al-Quran surat ke-7 ayat ke-57 menyebutkan: "Dan Dialah yang meniupkan angin sebagai pembawa berita gembira sebelum kedatangan rahmat-Nya (hujan), hingga apabila angin itu telah membawa awan mendung, Kami halau ke suatu daerah yang tandus, lalu Kami turunkan hujan di daerah itu, maka Kami keluarkan dengan sebab hujan itu pelbagai macam buahbuahan. Seperti itulah Kami membangkitkan orang-orang yang telah mati, mudah-mudahan kamu mengambil pelajaran".

Al-Quran surat ke-2 ayat ke-265 juga menjelaskan: "Dan perumpamaan orang-orang yang membelanjakan hartanya karena mencari keridhaan Allah dan untuk keteguhan jiwa mereka, seperti sebuah kebun yang terletak di dataran tinggi yang disiram oleh hujan lebat, maka kebun itu menghasilkan buahnya dua kali lipat. Jika hujan lebat tidak menyiraminya, maka hujan gerimis (pun memadai). Dan Allah Maha melihat apa yang kamu perbuat".

\section{f. Angin}

Al-Quran surat ke-10 ayat ke-22 menjelaskan: "Dialah Tuhan yang menjadikan kamu dapat berjalan di daratan, (berlayar) di lautan. sehingga apabila kamu berada di dalam bahtera, dan meluncurlah bahtera itu membawa orang-orang yang ada di dalamnya dengan tiupan angin yang baik, dan mereka bergembira karenanya, datanglah angin badai, dan (apabila) gelombang dari segenap penjuru menimpanya, dan mereka yakin bahwa mereka telah terkepung (bahaya), maka mereka berdoa kepada Allah dengan mengikhlaskan ketaatan kepada-Nya semata-mata. (Mereka berkata); sesungguhnya jika Engkau menyelamatkan kami dari bahaya ini, pastilah kami akan termasuk orang-orang yang bersyukur".

Sementara itu al-Quran surat ke-30 ayat ke-48 menyatakan: "Allah, Dialah yang mengirim angin, lalu angin itu 
menggerakkan awan dan Allah membentangkannya di langit menurut yang dikehendaki-Nya, dan menjadikannya bergumpal-gumpal, lalu kamu lihat hujan keluar dari celahcelahnya, maka apabila hujan itu turun mengenai hambahamba-Nya yang dikehendakiNya, tiba-tiba mereka menjadi gembira".

\section{Penerapan Kosmologi dalam Materi Pendidikan}

Ayat-ayat di atas menjelaskan materi pendidikan kosmologi dalam al-Quran yang meliputi unsur-unsur yang ada di daratan, lautan dan luar angkasa. Sedangkan untuk mengimplementasikan dalam kegiatan belajar mengajar diperlukan parameter atau alat ukur berupa kata kerja operasional yang digunakan sebagai pedoman dalam pembelajaran. Kata kerja operasional tersebut dirumuskan dari beberapa ayat yang biasa dipakai al-Quran dalam menjelaskan proses sebuah pekerjaan, yaitu:

1. Kata 'alima - ya'lamu (علم - يعلم).

2. Kata 'aqala-ya'qilu (عقل - يعقل).

3. Kata kerja faqiha-yafqahu (فقله - فيقل).

4. Kata fakkara-yufakkiru (فكر - يفكر).

5. Kata 'amala-ya'mulu (عمل- يعرل).

Lima kata kerja di atas dengan segala perubahannya dipilih karena al-Quran banyak menyebutkan dan memakainya. Seperti kata kerja 'alima - ya'lamu (علم - يعلم) dipilih karena banyak dipakai oleh alQuran dalam proses kegiatan dan aktifitas manusia dalam mengetahui segala sesuatu di alam semesta ini, sedangkan yang lainnya banyak terkait dengan sifat Allah SWT yang Maha Mengetahui. ${ }^{8}$ Kata aqala-ya'qilu (عقل- يعل) dipilih karena banyak

\footnotetext{
${ }^{7}$ Al-Quran surat ke-3 ayat ke-66; Al-Quran surat ke-6 ayat ke-81, Al-Quran surat ke-2 ayat ke-44; Al-Quran surat ke-3 ayat ke-65; Al-Quran surat ke-6 ayat ke-65; Al-Quran surat ke-63 ayat ke-7; Al-Quran surat ke-6 ayat ke-50; Al-Quran surat ke-2 ayat ke-219; Al-Quran surat ke-20 ayat ke-112; Al-Quran, surat ke-21 ayat ke-94. Lihat Departemen Agama RI, Al-Qur'an dan Terjemahannya (Jakarta: Yayasan Penyelenggara Penterjemah dan Penafsir al-Qur'an, 2009).

8 Kata kerja 'alima - ya'lamu (علم - يعلم) dengan segala perubahan kata diulang-ulang dalam al-Qur'an sebanyak 606 kali. Baca Departemen Agama RI, Al-Qur'an dan Terjemahannya (Jakarta: Yayasan Penyelenggara Penterjemah dan Penafsir al-Qur'an, 2009).
} 
dipakai al-Quran dalam kaitannya dengan perintah untuk memahami sesuatu keilmuan atau pengetahuan. Sedangkan kata kerja yang lain dipilih karena punya munasabat dengan tema indikator yang dikaji.

Aplikasi dalam praktik kependidikan, kata kerja tersebut dibuat menjadi kata kerja operasional yang menyertai materi pendidikan yang sudah ditemukan sebelumnya. Klasifikasi-klasifikasi kata kerja operasional disusun sebagai berikut:

Level 1: Mengetahui

Level 2: Memahami

Level 3: Berfikir, menganalisis. ${ }^{9}$

Level 4: Mengamalkan/mengerjakan/mengaplikasikan.

Level 1-4 kata kerja operasional di atas dipakai dalam menyusun tujuan pendidikan (Islam). Aplikasi kata kerja operasional yang menyertai materi pendidikan ini sangat penting untuk mengukur tingkat keberhasilan dan daya serap peserta didik terhadap materi yang telah diberikan. Indikator ketercapaian tujuan pendidikan tersebut dapat dilihat dalam tabel sebagai berikut:

\section{Tabel Aplikasi}

Materi Pendidikan Kosmologi

\begin{tabular}{|c|c|c|}
\hline $\begin{array}{c}\text { Jenis / } \\
\text { Kategori }\end{array}$ & Materi & Indikator Hasil Belajar \\
\hline $\begin{array}{l}\text { Kosmologi- } \\
\text { Daratan }\end{array}$ & & $\begin{array}{l}\text { Setelah mengikuti kegiatan } \\
\text { pembelajaran, peserta didik mampu: } \\
\text { 1. Mengetahui bumi dan isinya dan } \\
\text { apa yang dihasilkan oleh bumi. } \\
\text { 2. Memahami pentingnya } \\
\text { memanfaatkan bumi dan isinya } \\
\text { serta bagaimana merawatnya dari } \\
\text { kerusakan. }\end{array}$ \\
\hline
\end{tabular}

\footnotetext{
${ }^{9}$ Menganalisa dalam hal ini diartikan dengan "memahami sesuatu secara mendalam, penyeledikan terhadap suatu peristiwa untuk mengetahui keadaan yang sebenarnya, penguraian suatu pokok atas berbagai bagiannya dan penelaahan bagian itu sendiri serta hubungan antar bagian untuk memeroleh pengertian yang tepat dan pemahaman arti keseluruhan". Kamus Besar Bahasa Indonesia (Jakarta: Balai Pustaka, 2005 ed.3), 43.
} 


\begin{tabular}{|c|c|}
\hline $\begin{array}{l}\text { Bumi dan } \\
\text { Isinya }\end{array}$ & $\begin{array}{l}\text { 3. Berfikir tentang manfaat bumi } \\
\text { bagi umat manusia di dunia } \\
\text { 4. Menganalisa tindakan atau } \\
\text { kegiatan yang menyebabkan } \\
\text { kerusakan bumi dan bencana } \\
\text { alam serta bagaimana solusinya. } \\
\text { 5. Menerapkan teori-teori tentang } \\
\text { perawatan bumi dan } \\
\text { pemanfaatannya secara terukur } \\
\text { dan bertanggung jawab. }\end{array}$ \\
\hline $\begin{array}{l}\text { Tanah; } \\
\text { Pemanfaatan } \\
\& \\
\text { Pengelolaan- } \\
\text { nya }\end{array}$ & $\begin{array}{l}\text { Setelah mengikuti kegiatan } \\
\text { pembelajaran, peserta didik mampu: } \\
\text { 1. Mengetahui bagaimana cara } \\
\text { memaanfaatkan tanah dan segala } \\
\text { yang ada di dalamnya } \\
\text { 2. Memahami tatacara mengelola } \\
\text { tanah dan memanfaatkannya } \\
\text { secara bijak dan baik } \\
\text { 3. Menganalisa perbuatan dan } \\
\text { kegiatan yang menyebabkan } \\
\text { kerusakan tanah } \\
\text { 4. Menerapkan pengetahuan tentang } \\
\text { pengelolaan tanah dan } \\
\text { pemanfaatannya dalam } \\
\text { kehidupan sehari-hari. }\end{array}$ \\
\hline $\begin{array}{l}\text { Tumbuh- } \\
\text { tumbuhan; } \\
\text { Jenis-jenis } \\
\text { dan } \\
\text { pemanfaa- } \\
\text { tannya }\end{array}$ & $\begin{array}{l}\text { Setelah mengikuti kegiatan } \\
\text { pembelajaran, peserta didik mampu: } \\
\text { 1. Mengetahui ilmu tentang tumbuh- } \\
\text { tumbuhan dengan baik } \\
\text { 2. Memahami jenis-jenis tumbuh- } \\
\text { tumbuhan yang ada di sekitarnya. } \\
\text { 3. Menganalisa berbagai penyakit } \\
\text { dan hama yang bisa merusak } \\
\text { tumbuh-tumbuhan. }\end{array}$ \\
\hline
\end{tabular}




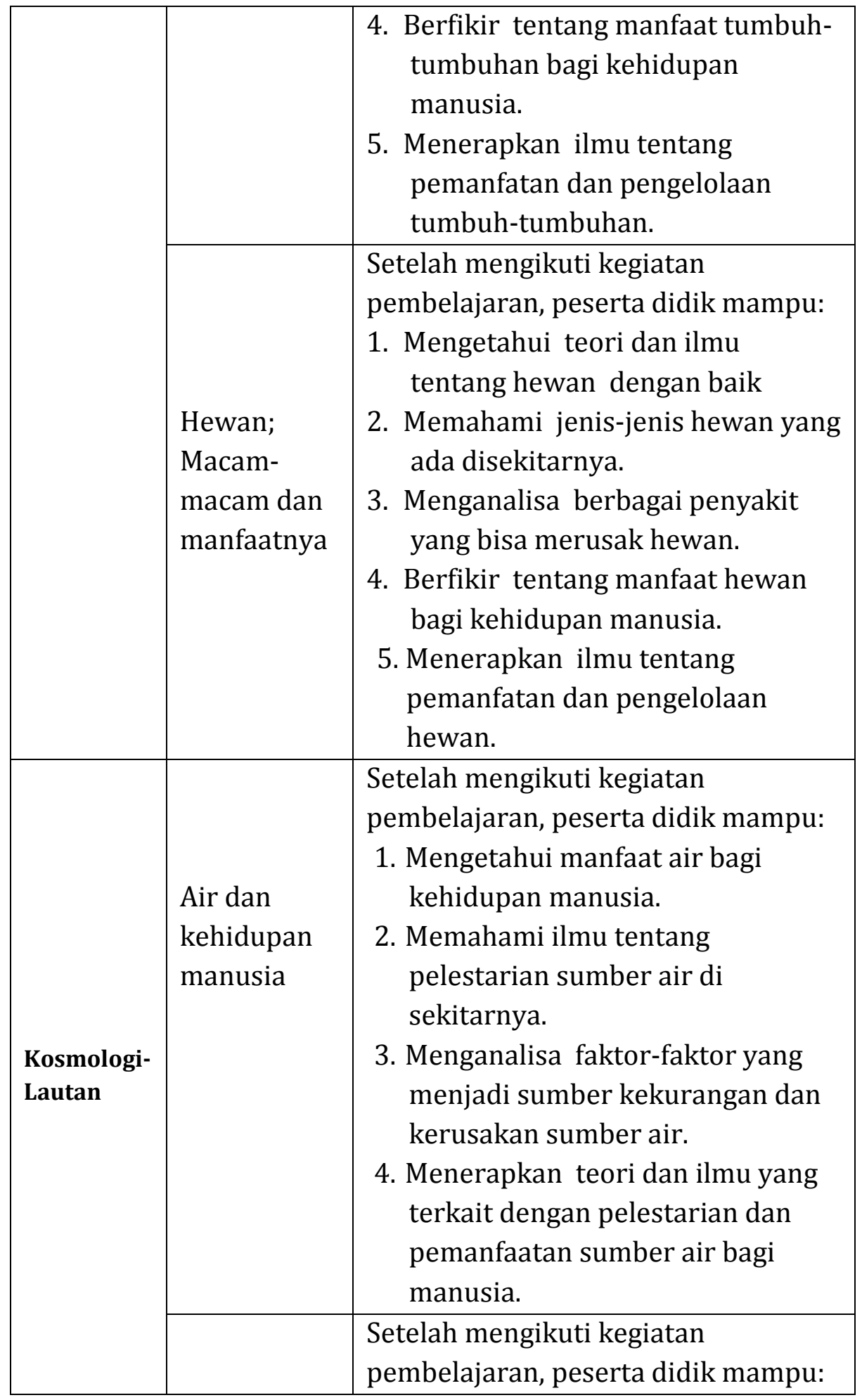




\begin{tabular}{|c|c|c|}
\hline & $\begin{array}{l}\text { Ikan dan } \\
\text { Manfaatnya } \\
\text { bagi } \\
\text { manusia }\end{array}$ & $\begin{array}{l}\text { 1. Mengetahui teori dan ilmu } \\
\text { tentang ikan dengan baik } \\
\text { 2. Memahami jenis-jenis ikan yang } \\
\text { ada disekitarnya. } \\
\text { 3. Menganalisa berbagai problem } \\
\text { yang merusak populasi ikan. } \\
\text { 4. Berfikir tentang manfaat ikan bagi } \\
\text { kehidupan manusia. } \\
\text { 5. Menerapkan ilmu tentang } \\
\text { pemanfatan dan pengelolaan } \\
\text { ikan. }\end{array}$ \\
\hline \multirow[t]{2}{*}{$\begin{array}{l}\text { Kosmologi- } \\
\text { Luar } \\
\text { Angkasa }\end{array}$} & $\begin{array}{l}\text { Matahari } \\
\text { dan } \\
\text { manfaatnya } \\
\text { bagi } \\
\text { kehidupan }\end{array}$ & $\begin{array}{l}\text { Setelah mengikuti kegiatan } \\
\text { pembelajaran, peserta didik mampu: } \\
\text { 1. Mengetahui manfaat matahari } \\
\text { dalam kehidupan manusia. } \\
\text { 2. Memahami pentingnya } \\
\text { memanfaatkan energi matahari } \\
\text { bagi kehidupan manusia. } \\
\text { 3. Menganalisa tindakan atau } \\
\text { kegiatan yang menyebabkan } \\
\text { kerusakan matahari dan bencana } \\
\text { alam serta bagaimana solusinya. } \\
\text { 4. Menerapkan teori-teori tentang } \\
\text { matahari dan manfaatannya } \\
\text { secara terukur dan bertanggung } \\
\text { jawab. }\end{array}$ \\
\hline & $\begin{array}{l}\text { Bulan dan } \\
\text { Manfaatnya } \\
\text { bagi }\end{array}$ & $\begin{array}{l}\text { Setelah mengikuti kegiatan } \\
\text { pembelajaran, peserta didik mampu: } \\
\text { 1. Mengetahui tentang eksistensi } \\
\text { bulan dalam tata surya. } \\
\text { 2. Memahami pentingnya rembulan } \\
\text { bagi sains dan kehidupan manusia. } \\
\text { 3. Berfikir tentang manfaat bulan }\end{array}$ \\
\hline
\end{tabular}




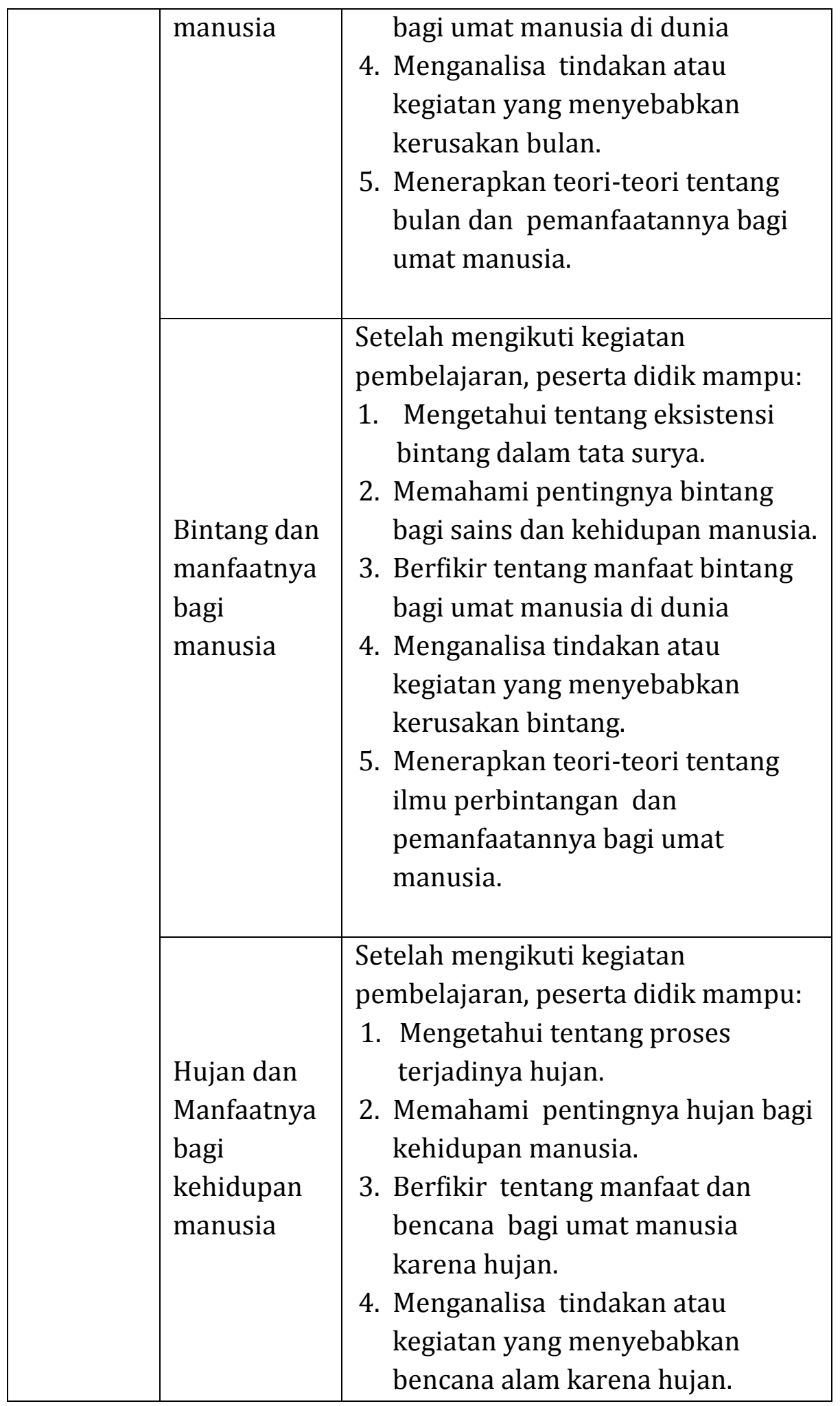




\begin{tabular}{|c|c|}
\hline & $\begin{array}{l}\text { 5. Menerapkan teori-teori tentang } \\
\text { hujan dan pemanfaatannya bagi } \\
\text { umat manusia. }\end{array}$ \\
\hline $\begin{array}{l}\text { Awan dan } \\
\text { Kehidupan } \\
\text { manusia }\end{array}$ & $\begin{array}{l}\text { Setelah mengikuti kegiatan } \\
\text { pembelajaran, peserta didik mampu: } \\
\text { 1. Mengetahui tentang awan dan } \\
\text { proses terjadinya hujan. } \\
\text { 2. Memahami pentingnya awan bagi } \\
\text { sains dan kehidupan manusia. } \\
\text { 3. Berfikir tentang manfaat awan } \\
\text { bagi umat manusia di dunia } \\
\text { 4. Menganalisa tindakan atau } \\
\text { kegiatan yang menyebabkan awan } \\
\text { menjadi sumber bencana bagi } \\
\text { manusia. } \\
\text { 5. Menerapkan teori-teori tentang } \\
\text { awan dan pemanfaatannya bagi } \\
\text { umat manusia. }\end{array}$ \\
\hline
\end{tabular}

Materi pendidikan kosmologi dan indikator hasil belajar pada tabel aplikasi di atas memberikan landasan bagi lembaga pendidikan (satuan pendidikan) untuk menyusun kontens materi lengkap yang diajarkan kepada peserta didik dengan hasil belajar seperti yang tertulis di tabel. Materi pendidikan kosmologi ini bisa diberikan pada jenjang pendidikan dasar, menengah, maupun perguruan tinggi dengan kedalaman materi dan kajian yang berbeda.

\section{E. Kesimpulan}

Kosmologi adalah ilmu yang mempelajari tentang asal-usul, struktur, hubungan antara ruang dan waktu dalam alam semesta. Kosmologi bermakna ilmu tentang asal usul kejadian bumi, hubungannya dengan sistem matahari, jagat raya, ilmu (cabang dari metafisika) yang mempelajari alam semesta sebagai sistem yang beraturan. Kosmologi sebagai ilmu (cabang filsafat) yang 
mempelajari tentang struktur, susunan dan keteraturan alam semesta. Al-Quran menjelaskan tentang alam semesta dengan segala isinya dengan ayat-ayat kawniyyah, dari ayat-ayat ini disusun dengan pendekatan tematik menjadi desain materi pendidikan kosmologi yang aplikatif bagi lembaga pendidikan.

Dengan pendekatan tematik (mawdhu'i) ayat-ayat al-Quran yang masih sangat luas bisa dibuat menjadi materi pendidikan kosmologi bagi lembaga pendidikan. Materi pendidikan kosmologi dalam al-Quran dibagi menjadi tiga jenis; 1) Kosmologi daratan yang meliputi bumi, tanah, tumbuh-tumbuhan dan hewan. 2) Kosmologi lautan yang meliputi air dan perikanan. 3) Kosmologi angkasa yang meliputi matahari, bulan, bintang, awan, hujan dan angin.

Sedangkan tujuan mempelajari materi pendidikan kosmologi agar menjadikan peserta didik dapat mengalola dan memanfaatkan alam semesta dan sumber dayanya dengan bijaksana, menghindari terjadinya bencana alam dan kekacauan serta ketidakteraturan alam semesta. Oleh karena itu materi pendidikan kosmologi/alam semesta (kawniyyah) mempunyai kedudukan yang sangat penting dalam pembelajaran pada lembaga-lembaga pendidikan terutama lembaga pendidikan Islam.

\section{DAFTAR PUSTAKA}

Arifin, M. 1993, Ilmu Pendidikan Islam: Suatu Tinjauan Teoritis dan Praktis Berdasarkan Pendekatan Interdisipliner (Jakarta: Bumi Aksara).

Departemen Agama RI., 2009, Al-Qur'an dan Terjemahannya (Jakarta: Yayasan Penyelenggara Penterjemah dan Penafsir al-Qur'an).

Farmawi, Abd Hayy, 2002, Al-Bidayah fi al-Tafsir Maudhu'i, Dirasah

Manhajiyyah Maudhu'iyyah, Terj. Rosihan Anwar (Bandung: Pustaka Setia).

Ibnu Jawzi, Zad al-Masir, dalam Al-Maktabah al-Syamilah, Akbar alMausuah Islamiyyah, Ihdhar Thani.

Ibnu 'Ashur, Al-Tahrir wa Al-Tanwir dalam Al-Maktabah al-Syamilah, Akbar al-Mausuah Islamiyyah, Ihdhar Thani. 
Ah. Zakki Fuad

Kamus Besar Bahasa Indonesia, 2005 (Jakarta: Balai Pustaka).

Nasir, Ridlwan, 2003, Memahami al-Quran Perspektif Baru Tafsir Muqarrin (Surabaya: Indra Media).

Tim Penulis Bahan Ajar PLPG, 2011, Perangkat Pembelajaran (Surabaya: LPTK Fak. Tarbiyah Surabaya). 